$9-1-1991$

\title{
The 'Vanity Fair' of Nineteenth-Century England: Commerce, Women, and the East in the Ladies' Bazaar
}

Gary Dyer

Cleveland State University, g.dyer@csuohio.edu

Follow this and additional works at: https://engagedscholarship.csuohio.edu/cleng_facpub

Part of the Literature in English, British Isles Commons

How does access to this work benefit you? Let us know!

Publisher's Statement

Article originally published as Dyer, Gary, "The Vanity Fair of Nineteenth-Century England:

Commerce, Women, and the East in the Ladies' Bazzar," Nineteenth-Century Literature, Vol. 46, No. 2 (Sept 1991): 196-222. (c) 2000 by The University of California Press.

\section{Recommended Citation}

Dyer, Gary, "The 'Vanity Fair' of Nineteenth-Century England: Commerce, Women, and the East in the Ladies' Bazaar" (1991). English Faculty Publications. 28.

https://engagedscholarship.csuohio.edu/cleng_facpub/28

This Article is brought to you for free and open access by the English Department at EngagedScholarship@CSU. It has been accepted for inclusion in English Faculty Publications by an authorized administrator of EngagedScholarship@CSU. For more information, please contact library.es@csuohio.edu. 


\title{
The "Vanity Fair" of Nineteenth-Century England: Commerce, Women, and the East in the Ladies' Bazaar
}

\author{
GARY R. DYER
}

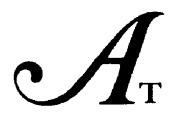

the conclusion of Thackeray's Vanity Fair (1847-48), Becky Sharp's wish to appear respectable leads her to work at a stall in a "fancy fair" benefiting the destitute, a charity bazaar that encapsulates the "Vanity Fair" to which the narrator has referred continually. This scene underscores the commercialism of "Vanity Fair," an aspect of how John Bunyan's phrase is applied that critics have appreciated insufficiently. The conclusion of the novel sums up Thackeray's concerns with deceit, class, and gender in a manner typical of what had become a topos in British writing; the author indeed revitalizes the distaste for business and the demonization of women common to the depictions of bazaars over the previous thirty-two years.

Early in 1816 John Trotter, having made a fortune supplying the army during the Napoleonic Wars, turned his warehouse on Soho Square in London into what he called a "bazaar," where women, particularly widows and orphans of army officers, could sell items they had made, renting counter space for three pence per foot daily. From the first, English bazaars were sites of conflict among cultural and moral values. The plan and rules of the

(C) 1991 by The Regents of the University of California 
Soho Square institution were shaped by its repression of particular examples of what Peter Stallybrass and Allon White, in their exemplary full-length study of hierarchies and identity in modern culture, discuss as the "low-Other." This bazaar, and its successors, evoked images that the upper- or middle-class English observer feared-Eastern exoticism (in the name "bazaar"), the marketplace, middle-class women going into business-so that it could contain and exorcise them. Observers nevertheless tended to assume that such attempts could not succeed; they assumed most crucially that the bazaars naturally would become sites of prostitution. Because bazaars quickly became integrated with misogynistic notions of feminine corruption and duplicity, the discursive tradition surrounding them implies that lust, greed, and deceit are women's essence and that they are sure to resurface. My purpose is to trace the bazaar topos through the early nineteenth century, analyzing in particular how Thackeray reiterates and revises this motif in Vanity Fair, when the ambivalence encoded in it not merely befits but shapes his sirenlike heroine Becky Sharp.

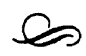

Trotter's establishment probably was the first in Britain to proclaim itself a "bazaar." 2 Despite its altruistic intent it brought him large profits, since it appealed to London customers by offering a variety of goods in one place; and the concept itself enjoyed corresponding success, "bazaars" opening (apparently for more directly commercial purposes) within a few months in Leicester Square, Newman Street, Bond Street, St.

${ }^{1}$ See The Politics and Poetics of Transgression (London: Methuen, 1986), p. 5 and passim. Following Stallybrass and White, I include in the low-Other not just the purely low but the hybrid, heterogeneous, and ambiguous-all those places and practices in which boundaries and hierarchies are transgressed. Bourgeois society construes as contamination the mixing of classes and other social and cultural categories that is essential to a marketplace or fair.

${ }^{2}$ The only earlier instance noted in the $O E D$ of the term being applied to a market outside the East is in Robert Southey's Letters from England (1807), where, however, the word appears to be simply the best comparison that occurs to the author's mouthpiece, Don Manuel Alvarez Espriella, a Spaniard visiting London, when he describes Exeter Change in the Strand (see Letters from England; by Don Manuel Alvarez Espriella ... Translated from the Spanish [London: Longman, 1807], I, 82). 
James's Street, and the Strand, and soon after in other British cities. ${ }^{3}$ William Jerdan wrote a long letter to The New Monthly Magazine on behalf of Trotter, explaining the Soho Bazaar in terms revealing that its benefit to unfortunate people was not the crucial aspect of its design on the ideological level. According to Jerdan, the bazaar would aid "a multitude of persons who have heretofore been condemned to penury and hopelessness by the insuperable difficulties and equally insuperable delicacies of their situation"-women in general and widows and orphans of the recently ended Napoleonic Wars in particular. Respecting the "insuperable delicacies" of their predicament clearly is more compelling to Jerdan than remedying its difficulties. Beyond its purely economic benefits, the bazaar "does not [d]rive woman from sacred home, but tells her to reside there in virtue, in peace, under the shield of security." Because as matters stand women can sell what they make only by means of wholesale dealers, with no profit to themselves, "the only excellent and approvable way in which women can employ themselves for a livelihood, has fallen into disuse." The "delightful scene of a family circle industriously engaged round its own fire" has become a thing of the past, and throughout the city one can see the results: "Unable to procure a livelihood at home, our females are sent abroad to work. The country pours its happy and innocent virgins into the common sink of London, and our streets are thronged with depravity and prostitution." 4 The bazaar would thus strengthen the traditional British family and fight prostitution by cutting off its supply of desperate young women. In Joseph Nightingale's count, of the two hundred people working at the Bazaar, only two were men, working alongside their wives (The Bazaar, pp. 42-43).

${ }^{3}$ See La Belle Assemblée, or Bell's Court and Fashionable Magazine, Addressed Particularly to the Ladies, n.s. 13 (April 1816), 191.

${ }^{4}$ William Jerdan, letter to the editor, The New Monthly Magazine and Universal Register (1 February 1816), 27-29. See also The Autobiography of William Jerdan, 4 vols. (London: Arthur Hall, 1852-53), II, 216-18. Another, more detailed justification of the Soho Bazaar, one quoting Jerdan's letter at length, is J[oseph] Nightingale, The Bazaar, Its Origin, Nature, and Objects Explained, and Recommended as an Important Branch of Political Economy; In a Letter to the Rt. Hon. George Rose, M.P.: To Which is Added a Postscript, Containing an Account of Every Establishment, Bearing This Name, in the Metropolis (London: Davies, Michael, and Hudson, 1816). 
Gathering women together in a public place, however, seemed to risk promoting the most immoral kind of trade. The bazaar required testimony of applicants' respectability, enforced strict rules of decorum, and limited business to the hours between ten in the morning and five in the afternoon, because without these precautions, Jerdan wrote, "such an establishment, instead of being a blessing, would be a curse; instead of encouraging the noblest of purposes, would be a sink of wickedness; instead of ameliorating the condition of society, would be the nurse of licentiousness and consequent misery." The Soho Bazaar still followed this original plan and respected its purposes a quarter-century later, as we learn from the account published in Charles Knight's London in 1843 (ten years after Trotter's death):

A plain and modest style of dress, on the part of the young females who serve at the stalls, is invariably insisted on, a matron being at hand to superintend the whole; every stall must have its wares displayed by a particular hour in the morning, under penalty of a fine from the renter; the rent is paid day by day, and if the renter be ill, she has to pay for the services of a substitute, the substitute being such an one as is approved by the principals of the establishment. ${ }^{6}$

This "well-ordered institution," one can assume, continued to demand social propriety and financial accountability until it closed in 1889.

The Soho Bazaar displayed a drive one might expect in a society that needed ideological unity as desperately as Britain did after Waterloo, a drive to conflate and control all that bourgeois sensibility demonized, whether the marketplace, the East, or women's power. In 1816 the enemy whose threat had kept the nation united for years had been exiled to St. Helena, and converting the economy from wartime to peacetime uses had nurtured unemployment and discontent, which were to lead to demonstrations and riots. Acknowledging Trotter's rationale of helping the unfortunate is only preliminary to interpreting his bazaar, and thereby perceiving how it was meant to isolate and protect the higher-class Englishman from those persons and ab-

${ }^{5}$ Jerdan, New Monthly Magazine letter, 31.

${ }^{6}$ Charles Knight, ed., London, 6 vols. (London: Charles Knight, 1841-44), V, 396. 
stractions he deemed peripheral or low, and how even the charitable purpose of the bazaar was covertly elitist. What determined Trotter's bazaar in 1816 was not only an appropriate concern for the war widows and other disadvantaged people privileged by Jerdan in the New Monthly Magazine but fear as well, fear felt toward several things: the East, the possibility of social classes mixing, the unruliness and crime associated with markets and fairs, the memory of the long and bloody Napoleonic Wars, and, most of all, women selling themselves-Jerdan's "common sink of London," streets "thronged with depravity and prostitution." Trotter dealt in symbols more than actualities: what he suppressed was not so much the small chance that his impoverished ladies would rent out their bodies as the conditions found where prostitutes congregated. As The Gentleman's Magazine went out of its way to note, Trotter's premises were "large, dry, commodious, well lighted, warmed, ventilated, and properly watched," and in each characteristic the Bazaar not merely differed from but opposed itself to the environs associated with prostitution. ${ }^{7}$

The remaining threats evoked by the bazaar, though meriting individual consideration, all likewise pertain to women, and particularly to women's social and economic power. Trotter's bazaar re-created on a much higher step of the social scale openair markets like those at Billingsgate, Covent Garden, and Hungerford, all staffed by women-London cousins of the Parisian poissardes whose rioting was a force in the French Revolution. Billingsgate is the crucial instance of such female impropriety, being noted for foul-mouthed fishwives. Halfway between these markets and Trotter's in social rank lay Exeter Change, established in the Strand in the seventeenth century, which Don Manuel Alvarez Espriella, the narrator of Southey's Letters from England, termed "precisely a Bazar, a sort of street under cover, or large long room, with a row of shops on either hand, and a thoroughfare between them" (p. 53). By moving the marketplace indoors, into a demarcated, regulated territory, Exeter Change foreshadowed the purification of the traditional market that was essential to the Soho Bazaar, but the resemblance extends no

${ }^{7}$ The Gentleman's Magazine, 86, pt. 1 (1816), 272. 
further: its great attraction, Edward Cross's menagerie, more befit Bartholomew Fair than it did a fashionable promenade, and the building lay in a dirtier, less homogeneous area, near such notorious centers of prostitution as Covent Garden and Drury Lane.

By choosing the name "bazaar" despite the Soho Square institution's marked differences from the markets of the East, Trotter intended to draw on the public's preconceptions of the Turkish and Arab world, which was a constant topic in British culture and thought-thousands read travel narratives or Byron's Eastern tales, and (to stay with the commercial and vulgar) toiletries were advertised as "oriental" or "Turkish." On 29 May 1816 Thomas Tegg published a print, "Genius, of Bazaar Arrived at London," showing a turbaned demon traveling from Turkey with the purpose of converting St. Paul's, the House of Commons, the British Museum, and other landmarks into bazaars (fig. 1). The inscription reads, "This Monster who is a Native of Turkey has lately made his appearance in London \& such is his power that by first appearing in Soho he got Acquainted with $\mathrm{Mr}$ Tr-t-r sinse which he has Spread Destruction through all the best houses in Town to the Great anoyance of all poor Shop-keepers." The concrete economic threat of the bazaars to British shopkeepers and the symbolic threat of the East to British values are made not analogous but homologous. What this caricature humorously presents as shopkeepers' fearful overinterpretation of the new bazaars is the very interpretation of the word "bazaar" that Trotter attempted to rewrite by applying it to virtuous English womanhood. As Edward W. Said and Rana Kabbani have demonstrated at length, people in Western societies perceive few human realities with more fear, fascination, and overriding hostility than "the Orient," that ideological construction positing the Islamic, Turkish, and Arab cultures as the opposite of "us" in "the Occident." " To associate the Oriental bazaar with Englishwomen-with "sacred home," "happy and innocent virgins"-is to assimilate, to domesticate that foreign presence and all it suggests, making it chaste, respectable, English.

${ }^{8}$ See Said, Orientalism (New York: Pantheon, 1978); and Kabbani, Europe's Myths of Orient (Bloomington: Indiana Univ. Press, 1986). 


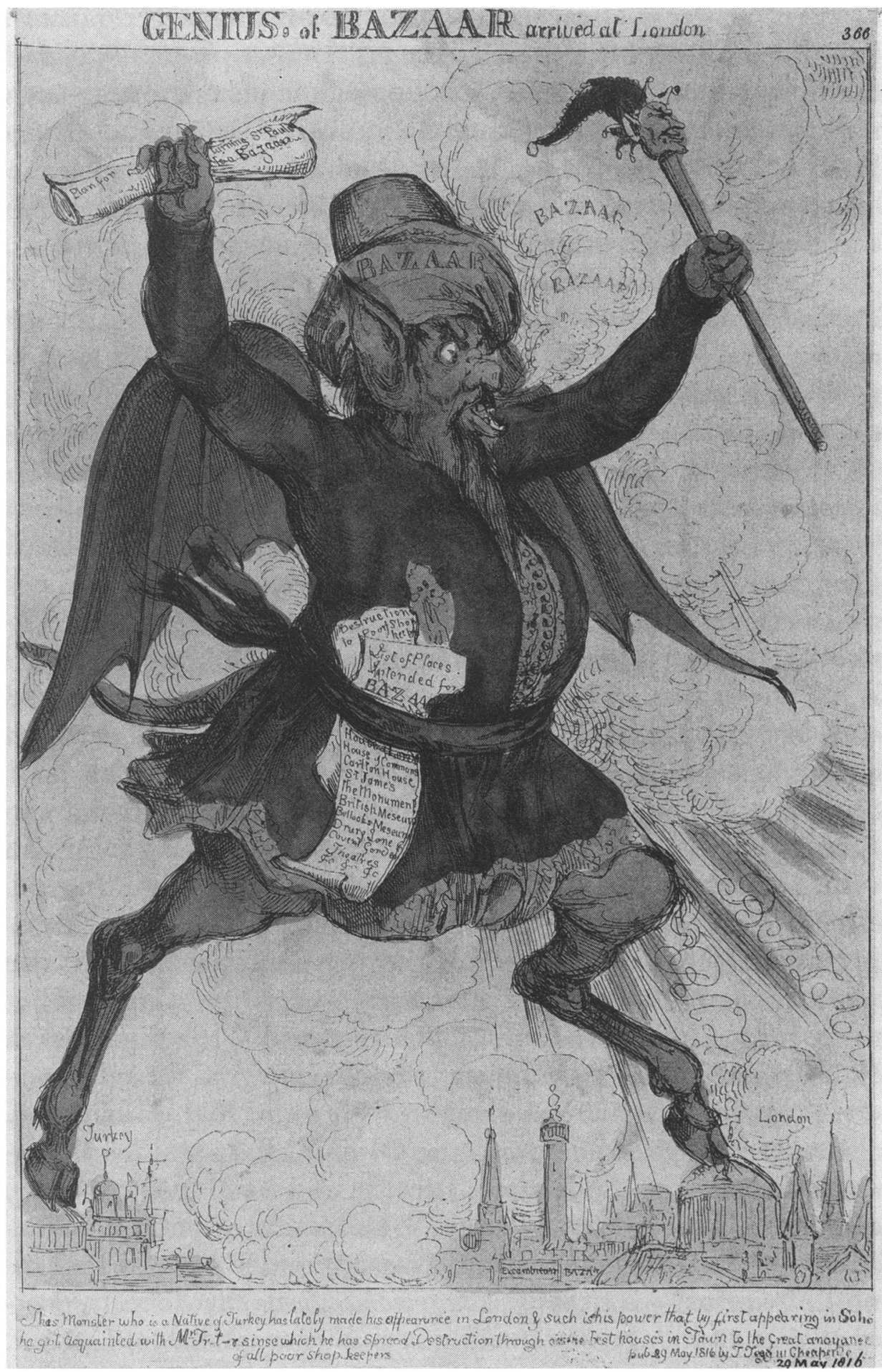

FIG. 1 
The term "bazaar," along with Trotter's project as a whole, was intended to evoke what was alien while rendering it powerless. Internalizing a threat in this manner nevertheless creates a potentially disruptive ideological and psychological contradiction, because one has not overcome fear but merely transferred its object from the outside to the inside of whatever demarcates one's identity (nation, gender, and so on).

The principal inconsistency of the bazaar concerned women. As I suggested, Trotter aimed to control what the term "bazaar" called forth by applying it to saintly English womanhood; however, invoking the English Lady as a talisman could not defeat the threat of the East entirely, not just because the East traditionally was associated with female sensuality but because women too were construed as essentially "other" (both the Orient and woman being foci of masculine desire). ${ }^{9}$ Although the Orient was the most clearly alien of the demons the bazaar evoked, it possessed a counterpart close to home: English womanhood. Applying a word hinting at the erotically charged Orient only served to acknowledge how the project fought against its author's regulatory impulse by giving women greater access to economic and social independence. The issue of women's empowerment was the point from which the bazaar project worked in two contrary directions, and from which conflicts are being played out in the depictions of bazaars from Jerdan's letter to Thackeray's Vanity Fair and beyond.

Whatever selfish goals we may suspect Trotter had in mind-transferring his building from one patriotic purpose to another, more presentable one, and transforming himself in the opinion of society from a war profiteer into a humanitarianshould not disguise how his aims typify the way the Soho Bazaar worked ideologically for its supporters and admirers. In the Soho Bazaar, praised by Leigh Hunt's Examiner for "its neatness, order, and general attention," 10 Trotter's entrepreneurial cleverness overcame the untidy, unsanitary, and unsupervised, much as it did in his own house, which Jerdan described years later:

${ }^{9}$ See Kabbani, passim.

${ }^{10}$ The Examiner, 431 (1816), 202. 
There were no noises, no bangings, no culinary odours anywhere but in the kitchen; everything neat, everything good, everything in its proper place, and nothing out of it; in short, all things disagreeable or inconvenient, which are often met with "in the best regulated families," were so transformed by his inexhaustible ingenuity, that he seemed to have the absolute command of every mechanical art. (Autobiography, II, 220)

The Bazaar regulated the sub-bourgeois in a manner analogous to that of such other products of the time as Regent Street, which its architect, John Nash, intended to be "a boundary and complete separation between the Streets and Squares occupied by the Nobility and Gentry, and the narrow streets and meaner Houses occupied by mechanics and the trading part of the community"11 (according to Nightingale, the Bazaar, for its part, did not admit as customers "persons meanly or dirtily dressed, or otherwise calculated to lessen the respectability of the place" [p. 16]). Even in trying to help war widows Trotter addressed the interests and concerns of the higher classes, since a bazaar transferred to these unfortunate women income that had fed and clothed people no less deserving, though perhaps less conspicuously respectable and needy. On 22 May London shopkeepers, noting that the "alarming mischief" of the bazaars "is extending itself to most commercial towns in the Empire," petitioned parliament to "avert the progress of the ruin which has already affected many important establishments," 12 but writers who commended the purpose of a bazaar at length generally ignored what cost it could have. The Bazaar strengthened class demarcations in regard to both whom it benefited financially and what it combated on the figurative level, although the means by which it affirmed the social hierarchy proved unconvincing to many (as we shall see) in establishing a safe, insular, moral zone.

"Accidents occur even in the best regulated families," reads the maxim Jerdan quoted only partially, and the guiding assumption behind representations of bazaars is that disasters must occur in regulatory schemes like Trotter's. Some observers

\footnotetext{
${ }^{11}$ Quoted in John Summerson, The Life and Work of John Nash, Architect (Cambridge, Mass.: MIT Press, 1980), p. 77.

${ }^{12}$ Journals of the House of Commons, 71 (1816), 389-90.
} 
saw the bazaars exemplifying the sordidness they were meant to prevent or exclude. In asking parliament for protection, the shopkeepers referred to "the numerous evils which must necessarily attend [the bazaars'] principle, as increasing places of public promenade, openings to intrigue, thus extending those mischiefs which they profess to remedy" (Journals, p. 390). It often was noted that visitors came only to look at the goods, while chatting with each other and with the counter women: "In London flashy shops behold, / And new bazaars, but nothing sold," wrote the anonymous author of the satirical poem "England in 1816," in which these establishments seem mere gilding for an unjust society. ${ }^{13}$ In 1823 Nathaniel Wheaton, an Episcopalian priest from Connecticut, visited what he termed "this great vanity-fair," a "fashionable lounge" patronized by "all who have nothing to do except to see and be seen." The mixing of the social classes in particular annoyed Wheaton (he noted "Ladies of quality and of no quality; citizens' wives and daughters-for your true republican equality is found only in a squeeze") ${ }^{14}$ but observers more often remarked on sexual impropriety, a related problem. In his print "A Bazaar" (fig. 2), published 1 June 1816, George Cruikshank made clear that the attractions of the bazaar included not only the clothes and other merchandise, but also women. On the far right a woman behind a counter shows goods to a leering dandy, telling him, "admire this Article you shall have it uncommonly cheap," and another man comments, "I dare say, for I'm sure it's second hand, \& common enough." Toward the left an overdressed, hunchbacked man tells a woman that he has "slipped a letter into that book naming time \& place"; holding the book, titled Innocent Adultery, she responds, "Very well-you rogue be punctual." To the right of them a woman tells an admirer, "I shall be at the Opera this Evening," while directly below this man a small boy rides a rather phallic hobbyhorse. Even the two dogs in the foreground are flirting. This market breeds deception, customers pretending to be what they

${ }^{13}$ La Belle Assemblée, n.s. 14 (November 1816), 224.

${ }^{14}$ Nathaniel S. Wheaton, A Journal of a Residence During Several Months in London; Including Excursions Through Various Parts of England; and a Short Tour in France and Scotland; in the Years 1823 and 1824 (Hartford, Conn.: H. and F. J. Huntington, 1830), pp. 180-90. 


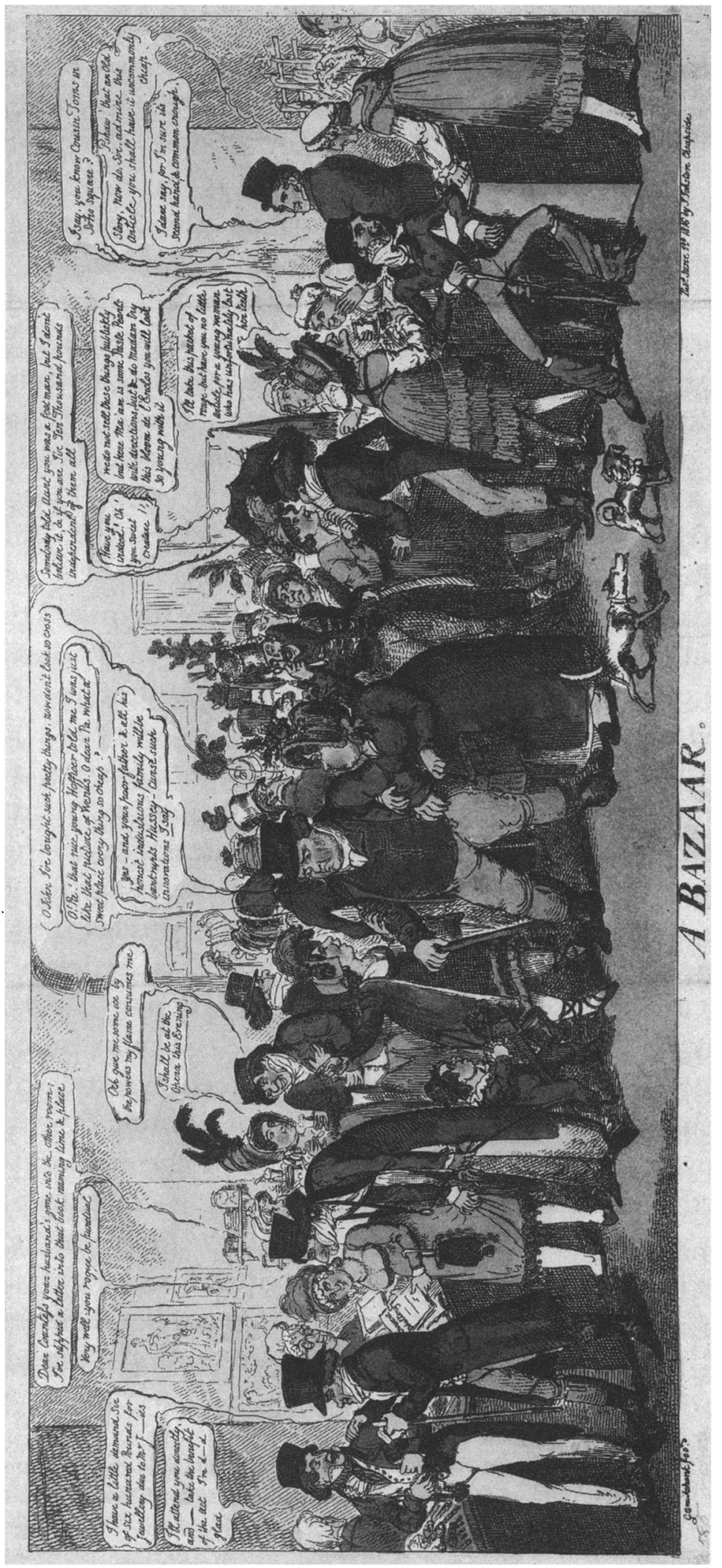


are not, as though they themselves are for sale: to the right of center a young woman tells a man that she cannot believe he is merely a footman, as her aunt claims; farther to the right a toothless old woman dressed in absurdly youthful clothes buys cosmetics.

Cruikshank's print emphasizes misbehavior among the customers; on the other hand, "Humphrey Hedgehogg"'s poem The London Bazaar, or, Where to Get Cheap Things, dated 9 June 1816, accuses the women working in the bazaars of outright prostitution (their bodies are the "cheap things" of his title):

In every street, and every lane,

A dashing new Bazaar is seen.

But many do not yet perceive

What cattle these Bazaars receive;

What bargains there are sold and bought-

But, 'faith, I mean of "female sort."

For, you must know, "th' industrious fair"

There-get a living by their "ware;"-

At least the world says such is true,

And there's no doubt but what they do.

One Captain Quiz bargains with a young woman over "the thing," and in assuring him of its quality she evokes the purpose of the Soho Bazaar, allowing women to enter business: "Till now 'twas ne'er put out for show; / But females, Captain, now-a-days / Must strive, and try a thousand ways / To earn their bread" (p. 10). This bazaar is supposedly regulated and safe: another woman tells Quiz, "Think how much better, clean and neat,/

\footnotetext{
${ }^{15}$ The London Bazaar, or, Where to Get Cheap Things: A Humorous Pindaric Poem (London: J. Duncombe, [1816]); the British Library catalog attributes this work to John Agg. All references are given parenthetically. Nightingale, on the other hand, claimed that the women working in the Bazaar have "neither time nor opportunity for the indulgence of levity: all is business and laudable emulation" (p. 52). In "Peter Pepperpod, Esq."'s satirical poem The Literary Bazaar; or the Poet's Council (which appeared late in 1816) the poets of England open a bazaar in order to free themselves from the yoke of booksellers, who alone profit from their writings as matters now stand. They resort to a bazaar despite how it dissolves their last pretense of transcending the marketplace, and this poem is significant because it shares with Hedgehogg's the assumption that commerce that tries to rise above disreputability must fail (Peter Pepperpod, Esq., The Literary Bazaar; or the Poet's Council: A Grand, Historic, Heroic, Serio-Comic, Hudibrastic Poem, in Two Cantos [London: for the author, 1816]).
} 
Are we than those who're in the street" (p. 13). But Quiz is being deceived-as the narrator puts the matter, "The thing by this 'Young Trader' poor, / Had been-aye! sold-ten times before" (p. 18)-and so the reader learns that this business is as conducive to the misrepresentations of salesmanship as it is to hazards like venereal disease. Cruikshank's and Hedgehogg's testimony reveals not that the London bazaars actually served as markets for women but that many assumed that these gatherings must become such, that their repressed referent, prostitution, would resurface. The crucial word in the shopkeepers' prediction that "numerous evils" will attend the bazaars is "necessarily." Such interpretations of the bazaars foreshadow those of later observers, particularly Thackeray, who emphasize the various kinds of feminine duplicity they perceive there. According to the common view, whatever the bazaar misrepresents-its purpose, the cleanliness of its products-the result indicts women doubly, because this trickery that disguises female promiscuity or greed is in itself characteristic of women.

Sometime in the 1820 s the term "bazaar" was appropriated for charitable fairs of a few days or weeks, often sponsored by Evangelical organizations; and much as the Soho Bazaar revised the outdoor marketplace to conform to the values of the middle and upper classes, the "fancy fair" or "ladies' bazaar" did the same for the traditional annual fair. In either case, the commercialism could be seen to degrade women, directly or indirectly, as Hannah More recognized: in an 1824 letter recording her contributions of poems to annual charity bazaars at Bristol, Clifton, and Bath, she writes that these literary "trifles" are more commercial, and hence "lower," than anything she would attempt for other motives. She jokes about being "brought so low as to write halfpenny papers," and a few years later, in 1827, she comments regarding such poems that she "never wrote for money before; but 'tis not for myself." 16

People perceived the women working in these temporary bazaars as the real merchandise; indeed, many unmarried young

${ }^{16}$ William Roberts, Memoirs of the Life and Correspondence of Mrs. Hannah More (New York: Harper, 1834), II, 374; Arthur Roberts, ed., Letters of Hannah More to Zachery Macaulay, Esq., Containing Notices of Lord Macaulay's Youth (New York: Robert Carter and Brothers, 1860), p. 203. 
women evidently did see a fancy fair as a means to display themselves. In Disraeli's novel The Young Duke (1831) the title character commences his affair with the married Lady Grafton at a bazaar that women of the elite have organized to benefit refugees from the Sandwich Islands, and the narrator begins this chapter, titled "Love at a Bazaar," with an ironic paean to the "miracle" that "ladies' hearts should be won, and gentlemen's also, not in courts of tourney or halls of revel, but over a counter and behind a stall." ${ }^{17}$ In one of his Sketches by Boz (1835), Dickens, noting the tendency of "the humbler classes" to imitate their superiors (the people of whom Disraeli wrote), draws the reader's attention to charity bazaars:

Aspiring young ladies, who read flaming accounts of some "fancy fair in high life," suddenly grow desperately charitable; visions of admiration and matrimony float before their eyes; some wonderfully meritorious institution, which, by the strangest accident in the world, has never been heard of before, is discovered to be in a languishing condition: Thomson's great room, or Johnson's nursery-ground, is forthwith engaged, and the aforesaid young ladies, from mere charity, exhibit themselves for three days, from twelve to four, for the small charge of one shilling per head! ${ }^{18}$

Although the transaction Dickens envisions is marriage rather than prostitution, the women who work in charity bazaars again are said to be the merchandise and not merely the vendors. In the July 1844 issue of The Christian Lady's Magazine, editor "Charlotte Elizabeth" (novelist Charlotte Elizabeth Phelan Tonna) solicited defenses or criticisms of fancy fairs from her pious readers, because "the custom [was] greatly on the increase of late," while she noted much the same phenomenon as Dickens did:

Young ladies, very far from taking an interest in the good works to be promoted, have often, very often been known to proffer aid for the avowed purpose (avowed to their friends) of having a flirtation with gentlemen buyers; and these gentlemen buyers, knowing this,

${ }^{17}$ The Young Duke: A Moral Tale, Though Gay, in The Works of Benjamin Disraeli, Earl of Beaconsfield, ed. Edmund Gosse (New York: AMS Press, 1976), III, 49-55.

18"London Recreations," in Sketches by Boz: Illustrative of Every-Day Life and EveryDay People (London: Oxford Univ. Press, 1957), p. 92. 
make no secret of their conviction, that all the young ladies who take stalls at a fancy fair, do so in order to be flirted with. ${ }^{19}$

The observation about charity bazaars running through all of these comments is that they remain fairs, marketplaces, retaining the amorality, the worldliness, and the tendency toward egalitarianism that those terms connote.

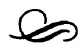

The depictions of English bazaars we have considered indicate that in these fairs realities that are base or peripheral are uneasily subsumed within the high or central and threaten to reemerge at any time. The advocate and the critic of bazaars usually share presuppositions about social and cultural hierarchy, but differ regarding how effectively the bazaar guards against disorderly realities like prostitution or the marketplace. The duality present in each bazaar is worth reiterating: in the world of The Christian Lady's Magazine, the world Becky Sharp has entered at the conclusion of Thackeray's novel, people perceived real danger in using worldly means for religious ends. In soliciting opinions, Charlotte Elizabeth was responding to a letter from one "H. A. N.," who, "Feeling that 'Christian Ladies' were the chief actors in these scenes, [was] somewhat surprised at the worldly tone, both of conduct and conversation, manifested in these engagements." ${ }^{20}$ Another correspondent, observing that organizers aimed to attract mainly "the lovers of pleasure rather than the lovers of GOD," feared mixing the moral and immoral, using terms more specifically religious than Jerdan's or Wheaton's but otherwise comparable: "all Christian people who are so engaged, run into unwarrantable temptations, inasmuch as they wilfully mingle with the ungodly and may learn their ways!"21

At the conclusion of Vanity Fair, Becky (styling herself "Lady Crawley," though her husband never held the family title) "is always having stalls at Fancy Fairs" on behalf of unfortunates like

\footnotetext{
${ }^{19}$ The Christian Lady's Magazine, 22, 1 (July 1844), 15-16.

${ }^{20}$ The Christian Lady's Magazine, 22, 1 (July 1844), 13.

${ }^{21}$ The Christian Lady's Magazine, 22, 5 (November 1844), 450-51.
} 


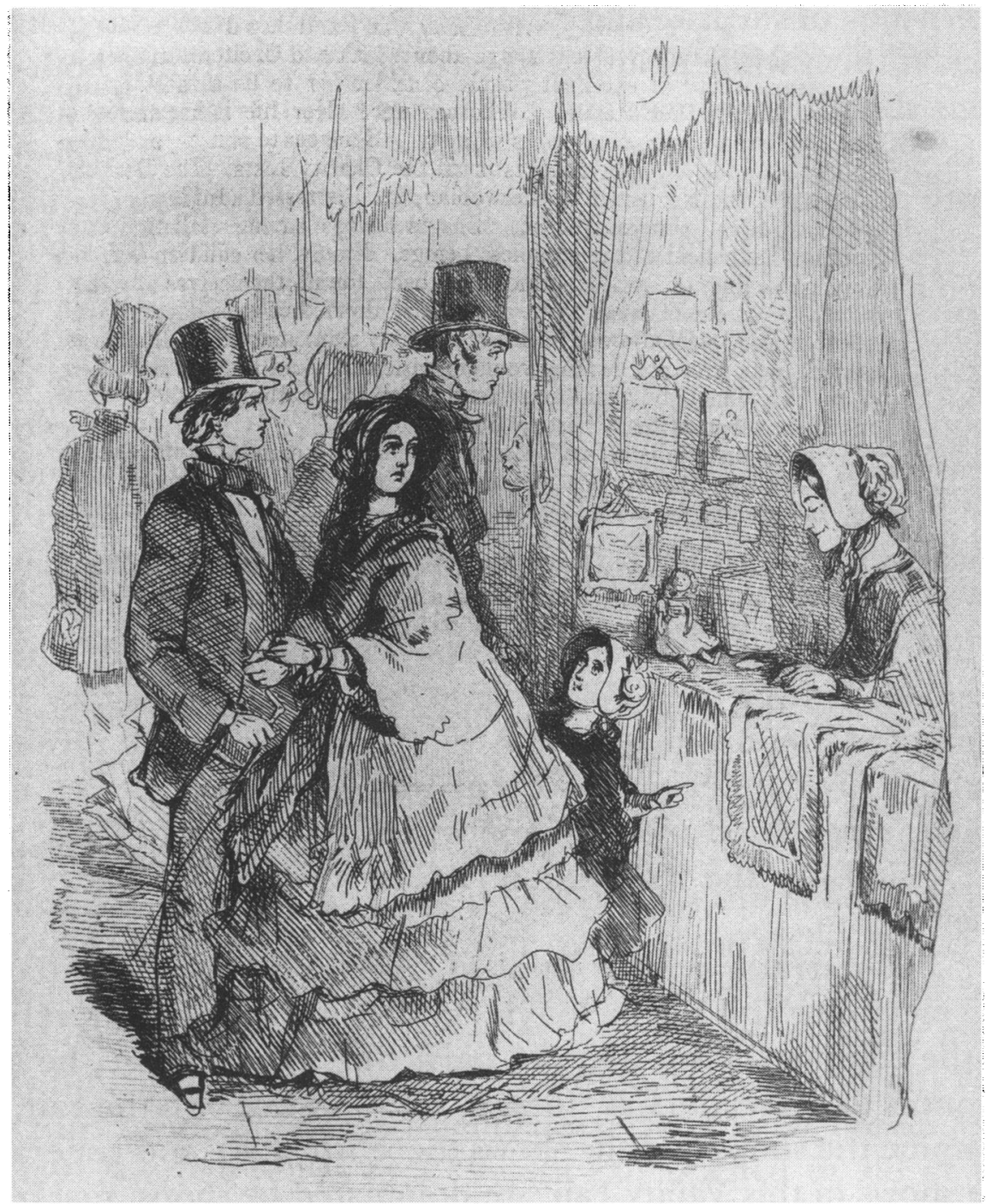

FIG. 3

"the Destitute Orange-girl, the Neglected Washerwoman, the Distressed Muffin-man" (p. 877) ${ }^{22}$ Amelia Osborne, her son George, her new husband William Dobbin, and their young daughter Jane come across Becky at a London bazaar. Thackeray's illustration (fig. 3) shows (on the right) Becky seated at a booth and (on the left) Amelia's family considering her, each

${ }^{22}$ All quotations are from Vanity Fair: A Novel Without a Hero, ed. John Sutherland (Oxford: Oxford Univ. Press, 1983). 
with a look of surprise and distaste, except for Jane, who glances back at them while pointing toward Becky, apparently both curious about this woman and her wares and intrigued by her elders' reaction. Thackeray titles the plate "Virtue rewarded; A booth in Vanity Fair," and, by ironically attributing virtue to his protagonist, he suggests that her pose of respectability, and indeed the entire fancy fair, conceals corruption and greed. That a fancy fair will represent Vanity Fair synecdochically is foreshadowed several times. Thackeray mentions in passing that upon arriving in central London Becky is "delighted beyond measure at the bazaars" (p. 32), and while these establishments would not have called themselves such in 1813, the term for Thackeray and his readers means a fair for a good cause. Later, unmarried Martha Crawley "furnishe[s] half the charity-bazaars in the county" (p. 499); out of desperation the widowed Amelia attempts to sell a crude painting to "the Fancy Repository and Brompton Emporium of Fine Arts" (p. 622). Scattered through the narrative are elements of our final glimpse of Becky: one woman's neglected mother "keeps a huxter's stall in Bath" (p. 472)-and at the conclusion Becky resides in Bath and Cheltenham.

The narrator applies Bunyan's phrase "Vanity Fair" (both as a metaphor and as a metonym) in such a manner that it refers to the commercialism there in particular. His purpose, he announces to his readers, is "to walk with you through the Fair, to examine the shops and the shows there" (p. 228), and generally the shows in this Vanity Fair are dominated by shops, markets, exchanges, and bazaars. According to John Sutherland, not just the title of the book but its locale, the Mayfair section of London, evokes traditional popular festivities:

Mayfair is so called, because the old May Fair used to be held there, just north of Piccadilly, from the middle ages up to the eighteenth century. ... Thackeray would have known about May Fair from his beloved Tatler, papers 4 and 20. And, of course, the fair inspires "Before the Curtain" [the prologue]. Thackeray was probably tickled by the fact that the old May Fair actually took place on a site where the modern Curzon Street (Becky and Rawdon live at 201) and Hertford Street (named after Steyne's original) now stand. . . . [T] he "fair" idea provided a theme which Thackeray could thread right through the novel: from riotous Vauxhall night in 1813, to Brussels en fête before Waterloo, to the junket at Gaunt House before Becky's Luciferian fall, 
to the Pumpernickel Grand-Ducal gala at which she bounces back, to the demure little charity "fair"-or bazaar-where Amelia finally encounters a rehabilitated "Lady" Crawley. ${ }^{23}$

Sutherland quotes John Timbs's Curiosities of London (1855) to the effect that May Fair was "not for trade" (p. xxxviii), a peculiarity that suggests it was only partially the model for Thackeray's figurative fair, to which buying and selling are so central. Bunyan, indeed, makes his Vanity Fair a center of commerce because, whatever purely allegorical value his concept may have, it is grounded in literal history and experience, in the Gospel account of Christ attacking the moneychangers in the temple, as well as in his own observation of Sturbridge Fair. Only in the nineteenth century did the phrase "vanity fair" enter the mainstream of the language (the $O E D$ lists no occurrences between 1678, when Pilgrim's Progress appeared, and 1816), and the rise of the bazaar helped: in addition to resembling the common near-synonym for bazaar, "fancy fair," the term evoked both the female pretense such places supposedly encouraged and the superfluity of the merchandise they usually offered: Nathaniel Wheaton, in a passage quoted earlier, calls the Soho Bazaar a "great vanity-fair"; the narrator in Walter Scott's Chronicles of the Canongate (1827) asks a mail-coach contractor how he will "answer one day for carrying so many bonny lasses to barter modesty for conceit and levity at the metropolitan [Edinburgh] Vanity Fair" (evidently a permanent bazaar); and in Sir Thomas More (1829) Southey refers to a "Vanity Fair opened in aid of the funds, under the title of a Ladies' Bazaar." ${ }^{4}$ Thackeray's Vanity Fair thus appeals not only to Bunyan's precedent but to recent, ongoing conventions interrelated with the charity bazaars. ${ }^{25}$

${ }^{23}$ Introduction to Vanity Fair, pp. xxxviii-xxxix.

${ }^{24}$ [Walter Scott,] Chronicles of the Canongate, 2 vols. (Edinburgh: Cadell and Co., 1827), I, 46; Robert Southey, Sir Thomas More: or, Colloquies on the Progress and Prospects of Society, 2 vols. (London: John Murray, 1829), II, 307.

${ }^{25}$ For interpretations of Thackeray's Fair in theological terms, see Joseph E. Baker, "'Vanity Fair' and the Celestial City," Nineteenth-Century Fiction, 10 (1955), 8998, and D. J. Dooley, "Thackeray's Use of Vanity Fair," Studies in English Literature, 11 (1971), 701-13. As Sutherland points out, the Vanity Fair motif also was taken up by Nathaniel Hawthorne in "The Celestial Railroad," first published in The United States Magazine and Democratic Review, 12 (1843), 515-23, and George Moir, "The Modern Pilgrim's Progress," Blackwood's Edinburgh Magazine, 59 (1846), 604-9 (in which Vanity Fair is stock speculation and the Stock Exchange). 
While Thackeray does not use the term "vanity fair" consistently, certainly it conveys how well English society of the $1820 \mathrm{~s}, 1830 \mathrm{~s}$, or $1840 \mathrm{~s}$ is represented by one of its practices, the charity bazaar. In May 1845 a huge bazaar was held at the Covent Garden Theater to benefit the Anti-Corn Law League, and since Thackeray did not think of the title for the novel until the autumn of 1846, this monumental fancy fair may have in part inspired his choice. ${ }^{26}$ Real life perhaps helped him relate bazaars to his protagonist as well: the mother of Theresa Reviss, one of his models for Becky, was "a girl in the Baker Street bazaar" who became the mistress of politician Charles Buller. ${ }^{27}$ Vanity Fair, at its core a novel of social and cultural history, describes the shift in English values between the dissolute Regency, when Becky's adventures begin, and the 1830 s, when she is settled behind a façade of virtue. Becky's fancy fair, the last "Vanity Fair" to which the narrator refers, sums up the others, while differentiating itself from them on historical grounds because the cultural reality it reflects is so recent. Concluding the narrative after the Reform Bill (1832), and after such other obvious milestones as Catholic Emancipation (1829) and the deaths of epochal figures like George IV (1830), makes the fancy fair where Becky sits seem to the 1848 reader not merely recent but contemporarythe present that the novel contrasts with the past in which most of the action takes place. The England of 1832 and later is like a charity bazaar, just as the England of 1813 was like Vauxhall Gardens, the Stock Exchange, or Exeter Change, all of which appear in the novel. The narrator declines to undercut Becky's ultimate performance at the fancy fair, as if to invite his reader to do so in practice for dealing with the similar misrepresentations found in mid-nineteenth-century England.

Sutherland writes that "Vanity Fair, the old May Fair and metropolitan Mayfair ... mingle in one, complex, saturnalian image" (p. xxxix), an image that, one should add, yokes together

${ }^{26}$ See The Illustrated London News, 6 (1845), 295-96, 309. A short satirical illustrated account of the bazaar appeared in Punch, 8 (1845), 216, and a caricature in that magazine envisioned Sir Robert Peel, in a wig, working at a booth (222).

${ }^{27}$ See W. G. Elliot, In My Anecdotage (London: Philip Allan, 1925), pp. 27-29. This and other references to Theresa Reviss are reproduced in The Letters and Private Papers of William Makepeace Thackeray, ed. Gordon N. Ray, 4 vols. (Cambridge, Mass.: Harvard Univ. Press, 1946), I, clvii-clx. 
two such incompatible Mayfairs that in the juxtaposition the past seems to expose meanings largely submerged in the present. Although (as Stallybrass and White observe, pp. 28-31) the traditional fair did not combine commerce with carnival (since participants did not assume from the first that the two were separate), the separation is a fact in Vanity Fair, which takes place when fairs had been restricted or suppressed increasingly for over a century, and when men like Trotter had in large part succeeded in creating homogeneous, clean places of business. If retail trade seemed "low" to the well-born or the ambitious in the time of Thackeray's novel, of all the elements of the fair it was the most justifiable, the most useful to bourgeois priorities. Commerce nonetheless served to suggest the fair in its entirety, no matter how tangentially it was related to other aspects of the event, like class-mixing. The energy, confusion, and heterogeneity essential to the traditional fair, and the fascinations and fears they could arouse, had been subsumed within conceptions of the Stock Exchange and the charity bazaar.

Business, and places of business, are the object of great ambivalence in the novel, since most of the characters belong to the commercial classes, who acquire money only to distance themselves from its taint. Money drives this society-George Osborne tells Amelia, "We live among bankers and city big-wigs," where "every man, as he talks to you, is jingling his guineas in his pocket" (p. 246) -yet these people wish to escape from their origins in business, rising above the world of the shop, "the Exchange," and "the City" to that of landed wealth, the acquisition of which preferably lies in the distant and obscure past. Dobbin's classmates condescend to him, as his father is a grocer and "the selling of goods by retail is a shameful and infamous practice, meriting the contempt and scorn of all real gentlemen" (pp. 4849)-whereas George Osborne's father, a "merchant," at least qualifies as a gentleman. Geographical distinctions reinforce the social barriers that separate Mr. Osborne and Mr. Sedley, who work in the City and live in questionable Russell Square, from the landed gentry who live farther west, like Lord Steyne. ${ }^{28}$

\footnotetext{
${ }^{28}$ For how business and businessmen are depicted in fiction of the period, see Norman Russell, The Novelist and Mammon: Literary Responses to the World of Commerce in the Nineteenth Century (Oxford: Clarendon Press, 1986).
} 
When Thackeray asks that his readers sympathize with Mr. Sedley, who has lost his fortune (and hence serves to show that "markets" are untrustworthy), he addresses them as "you to whom money and fair repute are the chiefest good; and so, surely, are they in Vanity Fair" (p. 243); the double meaning of "good" suggests that the Fair commodifies "fair repute" as if it were money.

Thackeray does not pretend to be neutral regarding the mentality of business; in his moral hierarchy it reflects badly on people that there is nothing they will not sell. The war trophies Becky sends to Miss Crawley on behalf of her husband, in order to win back the old woman's favor, are really items that "she bought for a few francs, from one of the innumerable pedlars who immediately began to deal in relics of the war" (p. 409). Thackeray implicitly compares Becky's lying and the peddler's parasitism, both of which are motivated by the desire for money. George Osborne explains to his impoverished fiancée his family's rejection of her by noting that "Ours is a ready-money society" (p. 246), and clearly the conflicting desires for "ready money" and for gentility hurt women most. Mrs. Crawley "sold [her heart] to become Sir Pitt Crawley's wife," and, the narrator comments, "Mothers and daughters are making the same bargain every day in Vanity Fair" (p. 176). Since the most conspicuous merchandise in Thackeray's world is young women, it is fitting that women there work at fancy fair stalls. I would argue, however, that no matter how Thackeray may satirize the greed or pretense of his society, or the restrictions that such drives place on women, he reaffirms the demonization of women essential to the bazaar topos. He associates women who confront the demands of society aggressively, represented by Becky, with the promiscuity supposedly natural to France, the exaggerated exoticism found in the game of charades at Lord Steyne's, and the false virtue of the fancy fair. Thackeray's illustration of "Virtue Rewarded" indeed implies that women by their nature are drawn to behavior like Becky's, when little Jane Dobbin appears attracted either to the fancy (meaning frivolous) goods that Becky sells, or to Becky's job at the bazaar.

In Vanity Fair Thackeray conflates various examples of the Other, much as the bazaar topos would lead us to anticipate, yet the East is introduced benignly, more so than we would expect 
from the author's earlier writings. In Notes of a Journey from Cornhill to Grand Cairo (1845) Thackeray (using the persona Michael Angelo Titmarsh) describes at length the bazaars of Near Eastern cities and implies they are essentially Oriental: when visiting Constantinople or Smyrna, "Walk into the Bazaar, and the East is unveiled to you," the East that a traveler already has studied so well in works like the Arabian Nights that "you may imagine that you have been in the place before." ${ }^{29}$ The commerce of the East is composed of misrepresentations: "the Orient is much maligned: but everybody cheats there: that is a melancholy fact" (p. 199). Thackeray memorably associates Becky with that region in the self-consciously Oriental charades played out at Lord Steyne's. Still, he generally identifies her pervasive foreignness otherwise, and he combines the Orient and commercialism most strikingly in the least threatening character in the novel, Joseph Sedley, who has made a small fortune with the East India Company. Thackeray's background is at issue here, since he owed the gentility of his own upbringing to wealth his family had made in India (and owed the loss of that wealth to the failure of Indiabased investment firms). He must transfer his antiheroine's alterity onto a country other than India while retaining a gentleman's distaste for the world of business, so he makes Becky halfFrench; hence she is disquietingly hybrid, contaminated by the traditional enemy of the English, an enemy they associated with promiscuity, frivolity, and indiscipline. In Notes of a Journey Thackeray comments that Smyrna, the first Turkish city he visited, "seems to me the most eastern of all I have seen; as Calais will probably remain to the Englishman the most French town in the world" (p. 60), and "A person who wishes to understand France and the East should come in a yacht to Calais or Smyrna, land for two hours, and never afterwards go back again" (p. 61). That is, the truth about Turkey or France is the shock of how it differs from England, and hence the two places are analogous, perhaps even interchangeable.

If Thackeray makes Becky's transgressiveness less Oriental, he only makes it more distinctly feminine. The pretense in which

${ }^{29}$ Notes of a Journey from Cornhill to Grand Cairo, By Way of Lisbon, Athens, Constantinople, and Jerusalem (London: Chapman and Hall, 1846), p. 62. Further references are given parenthetically. 
she indulges at the fancy fair is, of course, typical of this woman whose surname is slang for a swindler, and when the Vanity Fair narrator addresses the issue of duplicity at length the mythological imagery he chooses associates it with women in general. In a well-known passage at the beginning of chapter 64 the narrator attributes his reluctance to specify all of Becky's activities to the delicacy of the society that is both his audience and his subject: "In describing this siren," he writes, he has never "forgotten the laws of politeness, and showed the monster's hideous tail above water," and the extended siren metaphor for Becky makes clear that she is both dangerous and deceitful, and in a particularly feminine way: ${ }^{30}$

Those who like may peep down under waves that are pretty transparent, and see it writhing and twirling, diabolically hideous and slimy, flapping amongst bones, or curling round corpses; but above the water line, I ask, has not everything been proper, agreeable, and decorous, and has any the most squeamish immoralist in Vanity Fair a right to cry fie?

(pp. 812-13)

The famous siren image indicates, as forcefully as the concluding fancy fair does, that disguised corruption is natural to at least some women. As a metaphor the bazaar-lady nevertheless befits Thackeray's protagonist more than the siren does, simply because it both locates her deceit in the life of contemporary England and underscores how effectively she hides her darker aspects.

Thackeray, it must be emphasized, relates Becky's various trespasses not only to women but to English society of the first half of the nineteenth century. The bazaar is hardly the only example of false purity in this novel, for in Thackeray's London corruption and contamination are almost the norm-even the respected Lord Steyne's name suggesting "stain." Respectability often is evoked in terms of knowledge: the "best" people are, in the narrator's memorable phrasing, not "the most virtuous, or

${ }^{30}$ Judith Law Fisher interprets the siren metaphor in terms of artists and the commercialization of their work, in "Siren and Artist: Contradiction in Thackeray's Aesthetic Ideal," Nineteenth-Century Fiction, 39 (1985), 392-419. On the siren in relation to Thackeray's depictions of women, see particularly Nina Auerbach, Woman and the Demon: The Life of a Victorian Myth (Cambridge, Mass.: Harvard Univ. Press, 1982), pp. 88-101. 
indeed the least virtuous, or the cleverest, or the stupidest, or the richest, or the best born, but 'the best'-in a word, people about whom there is no question" (p. 636). Newly "honest" Becky decides she must no longer "be seen with doubtful people" (pp. 604-5), and when she doubts their respectability their ambiguity itself is disreputable. Admission to the best society involves as much forgetfulness as scrutiny, since about Becky there are many questions (of which no one has more than an attentive reader). "If [Becky] did not wish to lead a virtuous life, at least she desired to enjoy a character for virtue," and attaining that reputation entails being "presented to her sovereign at Court," a meeting from which one emerges with "a certificate of virtue" (p. 598). The metaphor of hygiene bespeaks how the highest social class has envisioned the threat of the lower, "doubtful" orders as that of disease:

[A]s dubious goods or letters are passed through an oven at quarantine, sprinkled with aromatic vinegar, and then pronounced cleanmany a lady whose reputation would be doubtful otherwise and liable to give infection, passes through the wholesome ordeal of the royal presence, and issues from it free from all taint. (p. 598)

Even if we could not infer the date by other means, this king could only be George IV, whose unwholesomeness Thackeray emphasizes in The Four Georges (1855). The text identifies the Regency and the reign of George IV with the failure to contain the threat Becky represents, much as it ultimately associates the 1848 reader's England with a place of more covert transgressions, the fancy fair.

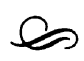

The bazaar topos persists into this century, along with charity bazaars themselves, and it is an open question precisely how much of that persistence is due to actual observation of these fairs and how much to the force of received notions about them and of earlier literary depictions. Certainly the same themes occur again and again in depictions of bazaars. As late as James Joyce's "Araby" (written in 1905), in which a Dublin boy travels to a charity bazaar to buy a present for his friend 
Mangan's sister, bazaars juxtapose the East, sexual promiscuity, and the indiscriminate with the clean, holy, and controlled, and again the locus of conflict is women.

The boy associates the girl with both the "romance" of the bazaar and the sacredness of the church, while separating both from all that is dirty, common, and commercial. The bazaar, called "Araby," casts "an Eastern enchantment" over him while he looks forward to it, even its name appearing "magical" (pp. 32, 34).$^{31} \mathrm{He}$ envisions his journey to this distinctly Eastern bazaar as a holy crusade or pilgrimage-fittingly, since his patronizing the bazaar will support church projects, both spiritual and worldly: what prevents the girl from visiting it herself is a retreat held by her convent school, and the bazaar Joyce had in mind, a six-day-long "Grand Oriental Fête" held in 1894, raised money for a hospital run by a Catholic order of sisters. ${ }^{32}$ The boy's ultimate disappointment is foreshadowed from the beginning of the story, for Joyce depicts as incongruous and corrupting the infiltration of worldly concerns like money into the sacred: the house where the boy lives belonged once to "a very charitable priest" (p. 29), and charity in this instance means not Christian caritas but giving money; a friend of the boy's aunt, as "a pawnbroker's widow" at the heart of commerce, "collected used stamps for some pious purpose" (p. 33). The boy's knowing elders assume that the East threatens the Catholic Church much as greed does, as one can infer from his aunt's fears that "Araby" might be "some Freemason affair" and, like Freemasonry, vaguely anti-Catholic, conspiratorial, and Oriental (p. 32). As for Mangan's sister, "Her image accompanied me even in places the most hostile to romance"; it accompanies him even when he goes "marketing" with his aunt:

We walked through the flaring streets, jostled by drunken men and bargaining women, amid the curses of labourers, the shrill litanies of shop-boys who stood on guard by the barrels of pigs' cheeks, the nasal chanting of street-singers, who sang a come-all-you about O'Donovan Rossa, or a ballad about the troubles in our native land.

(p. 31)

${ }^{31}$ All quotations are from "Dubliners": Text, Criticism, and Notes, ed. Robert Scholes and A. Walton Litz (New York: Viking Press, 1969).

${ }^{32}$ Don Gifford, Joyce Annotated: Notes for "Dubliners" and "A Portrait of the Artist as a Young Man," rev. ed. (Berkeley: Univ. of California Press, 1982), p. 40. 
The vulgarity of cursing laborers and drunken men, the greed of the "bargaining women," the facts of Ireland's subjugation, all disrupt his worship of the girl so much that he resorts to sacramental terms to separate her from this chaos, as if to counteract the shop-boys' mock-religious "litanies": "These noises converged in a single sensation of life for me: I imagined that I bore my chalice safely through a throng of foes" (p. 31). Because the narrator proceeds to tell how intense was his "confused adoration" of the girl, one tends to read this chalice figuratively as referring to either her or his feelings for her, when, ironically, it also refers to the parcels he is carrying for his aunt; worship entails repression, and in separating the girl from the chaos of the market he appropriates a symbol for her, the parcels, that because they originate in that place threaten to disrupt and betray his imaginative exaltation of her.

The bazaar, though silent like "a church after a service," turns out to be tainted by commerce and by suggestions of sexual availability; the sights that darken his mood are men counting coins and a young woman at one of the stalls flirting with two other men (pp. 34-35).$^{33}$ The boy has traveled to the east, literally as well as figuratively, but arrives only to see moneychangers in the Temple. A bazaar again conveys the falsehood of what men perceive to be above mundane, corrupt reality-conveys, to return to the boy's metaphor, that the chalice is actually a package. Joyce's conventional depiction of a bazaar demands an unjust inference about women in general: the boy seems to believe that the young woman at the bazaar reflects badly on Mangan's sister.

As we have seen, the bazaar topos encapsulates bourgeois antipathy toward commercialism and the East, as well as an ambivalent and ultimately fearful and hostile understanding of women. Many other British texts and institutions of the early nineteenth century adopted symbolically what was alien much

\footnotetext{
${ }^{33}$ The woman talking with the young men perhaps reflects the popular Irish consensus on women who worked in charity bazaars: in A Portrait of the Artist as a Young Man Heron mockingly calls Stephen Dedalus a "model youth" who not only does not smoke or flirt but does not "go to bazaars," bazaars where presumably young men loiter and available women are to be found ("A Portrait of the Artist as a Young Man": Text, Criticism, and Notes, ed. Chester G. Anderson [New York: Viking Press, 1968], p. 76).
} 
as the bazaar did, and such appropriation, one must suggest, was a necessary prerequisite and component of that country's imperial expansion. At the same time, the representation of women in works like Thackeray's reveals how traditional misogyny adapted itself to a Victorian reluctance to condemn women as sirens outright. It would be valuable to explore as well whether some women writing in novels and in their diaries interpreted the symbolism of charity fairs differently. Nevertheless, analysis of how the powerful evoke, mimic, and contain the low-Other must remain crucial to inquiry into constructions of the Other, simply because such adoption is a primary means by which domination is renewed.

University of Pennsylvania 